\title{
Effect of Irrigation Regimes and Varieties on Growth, Bulb Yield and Quality of Onion (Allium cepa L.)
}

\author{
Nisha Nandle, R.K. Sharma ${ }^{*}$, S.S. Kushwah and Roshan Gallani
}

Rajmata Vijayaraje Scindia Krishi Vishwavidyalaya, College of Horticulture, Mandsaur (Madhya Pradesh) - 458001, India

*Corresponding author

\begin{abstract}
Keywords
Irrigation regime, IW: CPE, Onion, Bulb, Water use efficiency etc.

Article Info

Accepted:

10 April 2018

Available Online:

10 May 2018 three levels of irrigation (1.0, 0.75 and 0.50 IW: CPE ratio) and three different varieties (NHRDF Red-1, NHRDF Red-3, Agrifound Light Red). The experiment was laid out in split plot design with three replications. The irrigation level $\mathrm{I}_{1}(\mathrm{IW}: \mathrm{CPE}=1.0)$ was found better for all growth attributes like plant height, number of leaves, fresh weight of plant, dry weight of plant, leaf area. The yield characters viz. dry weight of bulb, equatorial diameter, polar diameter, average weight of bulb and total yield of bulb were maximum in $\mathrm{I}_{1}$ (IW:CPE=1.0). Maximum neck thickness and T.S.S. of bulb was measured in case of irrigation level $\mathrm{I}_{1}$ (IW: $\mathrm{CPE}=1.00$ ). Highest water use efficiency was found with irrigation level $I_{1}$ which decreased with increase in irrigation interval (decreasing IW/CPE ratio). Variety $\mathrm{V}_{3}$ (Agrifound Light Red) recorded maximum plant height, number of leaves, fresh weight of plant, dry weight of plant, leaf area. Yield and yield parameters viz. maximum dry weight of bulb, equatorial diameter, polar diameter of bulb, average weight of bulb and total bulb yield per hectare were observed with $\mathrm{V}_{2}$ (NHRDF Red-3). Maximum neck thickness and highest T.S.S. content of bulb was recorded in case of $\mathrm{V}_{3}$ (Agrifound Light Red). Maximum Gross income, net income and B: C ratio was recorded under Irrigation level $\mathrm{I}_{1}(\mathrm{IW}$ : $\mathrm{CPE}=1.0)$ and variety $\mathrm{V}_{2}(\mathrm{NHRDF}$ Red-3).
\end{abstract}

\section{A B S T R A C T}

A field experiment was conducted at Vegetable Research Farm, College of Horticulture, Mandsaur (MP) during rabi season of 2014-15 to investigate the influence of irrigation regimes and varieties on growth, yield and quality of onion. The treatments comprised of

\section{Introduction}

Onion (Allium cepa L., $2 \mathrm{n}=16$ ) belonging to family Alliaceae is one of the most important bulbous vegetable crop grown in India from the ancient times. The word "Onion" is derived from Latin word which means "large pearl". It is compared to a pearl not only for its shape but also for its highly valuable nutritional and medicinal quality (Abd El-
Samad et al., 2011). Onion is a shallowrooted crop that requires frequent irrigation to achieve good yield. On irrigated land the onion crop is regarded as a fairly large consumer of water. Onion under water deficiency decreases in its evaporation and consequently yields (Sammis et al., 2000).

Irrigation is one of the most crucial inputs for onion production. Water is the main limiting 
factor for low productivity in onion. The shortage of irrigation at bulb development, which usually coincides with summer season, irrigation can replace the daily crop evapotranspiration.

Different combination of intensity, frequency and flow rates, affects the yield drastically. Hence, judicious use of water is very essential; one aim of irrigation is to replace the daily crop evapotranspiration. Different combination of intensity, frequency and flow rates can be customized to meet varying irrigation needs within a field.

Several studies examining water conservation and its effect on bulb yield imposed soil water-stress at some point during the growing period. In a trial with several vegetable crops, Singh and Alderfer (1966) observed that soilwater stress at any growth stage leads to reduction in marketable yield. They further observed that with regard to yield reduction, onions are more sensitive to water stress during bulb formation and enlargement than during the vegetative stage. There for, the present experiment was under taken to find out the response of onion to different levels of irrigation and varieties.

\section{Materials and Methods}

The experiment was conducted during rabi season of 2014-15 at Research Field (latitude of $23^{\circ} 45^{\prime}$ to $24^{0} 13^{\prime}$ north and longitude of $74^{0} 44^{\prime}$ to $75^{0} 18^{\prime}$ East) of the Department of Vegetable Science, College of Horticulture, Mandsaur (M.P.) located an elevation of $435.20 \mathrm{~m}$ above mean sea level with average annual rainfall is $544.05 \mathrm{~mm}$. The soil of the experimental field was light alluvial having sandy loam texture with uniform topography. The experiment was conducted with three levels of irrigation given at IW: CPE ratio of $1.0\left(\mathrm{I}_{1}\right), 0.75\left(\mathrm{I}_{2}\right)$, and $0.50\left(\mathrm{I}_{3}\right)$ as main plots and three varieties viz. NHRDF Red-1 $\left(\mathrm{V}_{1}\right)$,
NHRDF Red-3 ( $\left.\mathrm{V}_{2}\right)$ and Agrifound Light Red $\left(\mathrm{V}_{3}\right)$ as sub-plots. The experiment was laid out in split plot design with three replications in 27 well ploughed plots of $3.4 \mathrm{~m} \times 2.0 \mathrm{~m}$ size with a transplanting distance of $20 \mathrm{~cm} \times 10$ $\mathrm{cm}$. Recommended doses of nitrogen (120 $\mathrm{kg} / \mathrm{ha}$ ), phosphorus (50 kg/ha), potassium (60 $\mathrm{kg} / \mathrm{ha})$ and sulphur (25 kg/ha) were applied in each plot.

The source of nutrients was urea for nitrogen, SSP for phosphorus, MOP for potash and elemental sulphur for sulphur. Half dose of nitrogen with full dose of phosphorus, potash and sulphur were applied as basal dose prior to transplanting of onion seedlings. While the rest of nitrogen was given in 2 equal split doses in onion crop, first at 20 and second at 45 days after transplanting. Standard practices for onion production were followed. Irrigation was given on the basis of CPE which was recorded from Pan Evaporimeter installed in the field. The crop was harvested when $75 \%$ tops start falling over but before the foliage is completely dry. The bulbs are harvested by hand pulling and with the help of hand hoe.

The tops were removed one day after field curing leaving $2.5 \mathrm{~cm}$ top only with the bulb. Plant growth parameters, i.e. plant height, number of leaves, fresh and dry weight of plant and leaf area were recorded during the experiment. The yield attributes and yield (Dry weight of bulb, polar diameter, equatorial diameter, average weight of bulb and bulb yield) were recorded at the time of harvest. The quality parameters, viz. neck thickness and total soluble solids were determined using standard procedure. At the end of experiment, total amount of water applied was calculated and water use efficiency was calculated by dividing total bulb yield with total water used by the crop.

Water use efficiency $=$ Total yield of bulbs (Tonnes/ha) /total water applied $(\mathrm{cm})$ 


\section{Results and Discussion}

\section{Growth parameters}

Growth of the onion was studied with respect to plant height and number of leaves per plant at 30,60, 90 days after transplanting and at harvesting stage. Whereas the data on fresh weight, dry weight of plant and leaf area per plant were taken at 30,60 and 90 days after transplanting. There was significant effect of varieties and irrigation levels on all the growth parameters (Table 1). Among the irrigation levels, the maximum value of plant height was recorded under irrigation level $\mathrm{I}_{1}$ $(\mathrm{IW} / \mathrm{CPE}=1.00)$ which was followed by irrigation level $\mathrm{I}_{2} \quad(\mathrm{IW} / \mathrm{CPE}=0.75)$ while minimum value of plant height was recorded by irrigation level $\mathrm{I}_{3}$ (IW/CPE=0.50). This increased growth may be due to the increase in turgidity of the cells with the increase in available soil moisture leads to increase cell division and enlargement. Similar findings were obtained by Neeraja et al., (1999) and Metwally (2011). During all the stages of growth, cultivar $\mathrm{V}_{3}$ (Agrifound Light Red) recorded higher value of plant height than the cultivar $\mathrm{V}_{2}$ (NHRDF Red-3). Minimum plant height was indicated in $\mathrm{V}_{1}$ (NHRDF-Red-1). This variation in morphological trait is because of their genetic make-up. These findings were in agreement with those of Mohanty and Prustil (2001) and Jogdande et al., (2011).

Irrigation regime had exhibited significant effect on number of leaves per plant at all the growth stages of onion. Among the irrigation levels, the maximum value of number of leaves per plant was recorded under irrigation level $\mathrm{I}_{1}(\mathrm{IW} / \mathrm{CPE}=1.00)$ which was followed by irrigation level $\mathrm{I}_{2}$ (IW/CPE=0.75), while minimum value of plant height was recorded by irrigation level $\mathrm{I}_{3}(\mathrm{IW} / \mathrm{CPE}=0.50)$. Similar findings have been also found by Neeaja et al., (1999), Sharda et al., (2006) and Biswas et al.,
(2010). In the present study variety $\mathrm{V}_{3}$ (Agrifound Light Red) recorded a higher mean value of number of leaves per plant than the verity $\mathrm{V}_{2}$ (NHRDF Red-3) at different stages of growth. Varity $\mathrm{V}_{1}$ (NHRDF Red-1) recorded minimum number of leaves at all the stages of the crop growth. These findings corroborates with those of Yumnam et al., (2009).

In general, there was increase in fresh weight of plant up to 90 DAT. The irrigation levels had exerted significant effect on fresh weight of plant. The maximum value of fresh weight of plant at all stages of observation was recorded by irrigation level $\mathrm{I}_{1}(\mathrm{IW} / \mathrm{CPE}=1.00)$ followed by irrigation level $\mathrm{I}_{2}$ (IW/CPE $=0.75$ ), while the minimum fresh weight of plant was found under irrigation level $\mathrm{I}_{3}(\mathrm{IW} / \mathrm{CPE}=0.50)$ at all the stages of crop study. These findings are in agreement with Abd El-Kader et al., (2010) in okra. The results revealed that different varieties had significant difference on fresh weight of plant at all the stages of plant growth. Variety $V_{3}$ (Agrifound Light Red) recorded highest fresh weight of plant followed by the variety $\mathrm{V}_{2}$ (NHRDF Red-3). Variety $\mathrm{V}_{1}$ (NHRDF Red-1) had registered minimum fresh weight of plant at all stages. Higher plant height and number of leaves might have resulted in more photosynthesis and accumulation of food material in $\mathrm{V}_{2}$ and $\mathrm{V}_{3}$ resulting in higher fresh weight of plant. These findings corroborates with those of Devi et al., (2014).

Dry weight of plant at all stages of observation showed significant influence of irrigation levels. Among the irrigation levels the maximum dry weight of plant was recorded with irrigation level $\mathrm{I}_{1}(\mathrm{IW} / \mathrm{CPE}=1.00)$ as compared to other irrigation levels. More frequent irrigation resulted in higher dry matter accumulation in plant. These findings are in line with Metwally (2011). Data recorded in the present study indicated that 
maximum dry weight of plant was recorded with variety $\mathrm{V}_{3}$ (Agrifound Light Red) which was followed by $V_{2}$ (NHRDF Red-3) and minimum dry weight of plant was recorded in $\mathrm{V}_{1}$ (NHRDF Red-1). More number of leaves and greater plant height might have enhanced the photosynthesis, accumulation of photosynthesis consequently in higher fresh weight and dry weight of plant in cultivar Agrifound Light Red.

Leaf area of plant recorded at 30,60, and 90 DAT was significantly affected by irrigation levels. Among the irrigation levels the maximum leaf area of plant was recorded with irrigation level $\mathrm{I}_{1}(\mathrm{IW} / \mathrm{CPE}=1.00)$ which was followed by irrigation level $\mathrm{I}_{2}(\mathrm{IW} / \mathrm{CPE}=0.75)$ while the minimum leaf area of plant was recorded in case of irrigation level $\mathrm{I}_{3}$ (IW/CPE $=0.50)$. More frequent irrigation resulted in more number of leaves might be the reason of greater leaf area in irrigation level $\mathrm{I}_{1}$. Similar findings have been reported by Abd El-Kader et al., (2010) in okra. Data recorded in the present study indicated that variety $V_{3}$ (Agrifound Light $\mathrm{Red}$ ) had maximum leaf area per plant which was followed by the variety $\mathrm{V}_{2}$ (NHRDF Red-3). Minimum leaf area per plant was observed in variety $\mathrm{V}_{1}$ (NHRDF-Red-1). More plant height and number of leaves might be the reason of greater leaf area in $\mathrm{V}_{3}$.

\section{Yield parameters}

Yield attributes viz. dry weight of bulbs, equatorial diameter, polar diameter, average weight of bulb and bulb yield per hectare were recorded to study the impact of different irrigation levels and varieties on onion (Table 2). Observations showed significant effect of irrigation levels and varieties on dry weight of bulb. Among the irrigation levels, the maximum dry weight of bulb was recorded with irrigation level $\mathrm{I}_{1} \quad(\mathrm{IW} / \mathrm{CPE}=1.00)$ as compared to other irrigation regimes. More frequent irrigation resulted in higher dry weight of bulb accumulation in plant. These findings corroborates with those of Neeraja et al., (1999) and Sharda et al., (2006). In the present study variety $\mathrm{V}_{2}$ (NHRDF Red-3) recorded a higher mean value of dry weight of bulb than the variety $V_{3}$ (Agrifound Light Red) while the minimum dry weight of bulb was measured in case of variety $\mathrm{V}_{1}$ (NHRDF Red-1). Though the variety $V_{3}$ has showed higher growth attributes as compared to $\mathrm{V}_{2}$ but better photosynthetic translocation efficiency of $\mathrm{V}_{2}$ might have resulted in more accumulation of food material in dry matter.

Equatorial diameter of bulb was recorded at harvesting stage. The data exhibited significant effect of irrigation levels and varieties on equatorial diameter of bulb $(\mathrm{cm})$. Among the irrigation levels the maximum equatorial diameter of bulb was recorded with irrigation level $\mathrm{I}_{1}(\mathrm{IW} / \mathrm{CPE}=1.00)$ which was followed by $\mathrm{I}_{2}(\mathrm{IW} / \mathrm{CPE}=0.75)$ while the minimum equatorial diameter of bulb was recorded in case of irrigation level $\mathrm{I}_{3}$ (IW/CPE=0.50). Neeraja et al., (1999), Sharda et al., (2006) and Metwally (2011) in onion have also found similar effect of irrigation levels on equatorial diameter of bulb.

Equatorial diameter of bulb was significantly affected by varieties. In the present study variety $\mathrm{V}_{2}$ (NHRDF Red-3) recorded a higher mean value of equatorial diameter than the variety $V_{3}$ (Agrifound Light Red) whereas the minimum equatorial diameter was measured in case of variety $\mathrm{V}_{1}$ (NHRDF-Red-1).

Observations recorded on polar diameter of bulb of onion varieties as significantly influenced by various irrigation regimes. The maximum polar diameter of bulb was recorded with irrigation level $\mathrm{I}_{1}(\mathrm{IW} / \mathrm{CPE}=1.00)$ which was followed by $\mathrm{I}_{2}(\mathrm{IW} / \mathrm{CPE}=0.75)$ while the minimum polar diameter of bulb was recorded in case of irrigation level $\mathrm{I}_{3}$ (IW/CPE=0.50). 
Table.1 Effect of irrigation levels and varieties on growth attributes of onion

\begin{tabular}{|c|c|c|c|c|c|c|c|c|c|c|c|c|c|c|c|}
\hline \multirow[t]{2}{*}{ Treatment } & \multicolumn{3}{|c|}{ Plant height (cm) } & \multicolumn{3}{|c|}{ No. of leaves per plant } & \multicolumn{3}{|c|}{ Fresh weight of plant (g) } & \multicolumn{3}{|c|}{ Dry weight of plant (g) } & \multicolumn{3}{|c|}{ Leaf area per plant $\left(\mathrm{cm}^{2}\right)$} \\
\hline & $\begin{array}{c}30 \\
\text { DAT }\end{array}$ & $\begin{array}{c}60 \\
\text { DAT }\end{array}$ & $\begin{array}{c}90 \\
\text { DAT }\end{array}$ & $\begin{array}{c}30 \\
\text { DAT }\end{array}$ & $\begin{array}{c}60 \\
\text { DAT }\end{array}$ & $\begin{array}{c}90 \\
\text { DAT }\end{array}$ & $\begin{array}{c}30 \\
\text { DAT }\end{array}$ & $\begin{array}{c}60 \\
\text { DAT }\end{array}$ & $90 \mathrm{DAT}$ & $\begin{array}{c}30 \\
\text { DAT }\end{array}$ & $\begin{array}{c}60 \\
\text { DAT }\end{array}$ & $\begin{array}{c}90 \\
\text { DAT }\end{array}$ & $\begin{array}{c}30 \\
\text { DAT }\end{array}$ & $\begin{array}{c}60 \\
\text { DAT }\end{array}$ & $\begin{array}{c}90 \\
\text { DAT }\end{array}$ \\
\hline \multicolumn{16}{|l|}{ Irrigation levels (I) } \\
\hline $\mathrm{I}_{1}(\mathrm{IW} / \mathrm{CPE}=1.0)$ & 28.58 & 69.77 & 80.57 & 5.50 & 7.17 & 10.55 & 6.53 & 23.81 & 95.01 & 1.22 & 1.67 & 3.32 & 52.46 & 167.10 & 371.97 \\
\hline $\mathrm{I}_{2}(\mathrm{IW} / \mathrm{CPE}=0.75)$ & 25.53 & 65.74 & 75.58 & 4.75 & 7.08 & 10.20 & 5.69 & 22.18 & 86.81 & 1.00 & 1.51 & 3.14 & 38.85 & 151.75 & 326.62 \\
\hline $\mathrm{I}_{3}(\mathrm{IW} / \mathrm{CPE}=\mathbf{0 . 5 0 )}$ & 22.67 & 59.17 & 63.67 & 4.23 & 5.89 & 8.45 & 3.89 & 18.46 & 81.13 & 0.87 & 1.08 & 2.82 & 32.14 & 137.74 & 288.93 \\
\hline S.Em \pm & 0.58 & 1.65 & 1.61 & 0.08 & 0.15 & 0.19 & 0.09 & 0.50 & 1.48 & 0.05 & 0.01 & 0.07 & 1.06 & 4.08 & 5.85 \\
\hline \multicolumn{16}{|l|}{ Varieties (V) } \\
\hline V $_{1}$ (NHRDF Red-1) & 24.07 & 58.37 & 69.12 & 4.44 & 5.74 & 8.83 & 4.83 & 18.20 & 78.42 & 0.81 & 1.37 & 2.67 & 35.15 & 130.41 & 296.17 \\
\hline V $_{2}$ (NHRDF Red-3) & 25.51 & 64.40 & 73.88 & 4.75 & 7.09 & 9.89 & 5.39 & 22.31 & 87.49 & 1.04 & 1.39 & 3.07 & 41.71 & 150.66 & 334.76 \\
\hline $\mathbf{V}_{3}$ (Agrifound Light Red) & 27.21 & 71.91 & 75.94 & 5.29 & 7.33 & 10.49 & 5.88 & 23.23 & 97.06 & 1.25 & 1.51 & 3.54 & 46.58 & 175.52 & 356.59 \\
\hline S.Em \pm & 0.76 & 1.84 & 1.50 & 0.18 & 0.18 & 0.26 & 0.15 & 0.58 & 2.40 & 0.03 & 0.02 & 0.09 & 1.12 & 4.23 & 9.01 \\
\hline CD at $5 \%$ & 2.36 & 5.69 & 4.62 & 0.55 & 0.56 & 0.82 & 0.46 & 1.81 & 7.41 & 0.12 & 0.08 & 0.30 & 3.42 & 13.04 & 27.79 \\
\hline
\end{tabular}

Table.2 Effect of irrigation levels and varieties on yield, quality, WUE and economics of onion

\begin{tabular}{|c|c|c|c|c|c|c|c|c|c|c|c|}
\hline Treatment & $\begin{array}{c}\text { Dry } \\
\text { weight } \\
\text { of bulb } \\
\text { (g) }\end{array}$ & $\begin{array}{l}\text { Equatorial } \\
\text { diameter of } \\
\text { bulb }(\mathrm{cm})\end{array}$ & $\begin{array}{l}\text { Polar } \\
\text { diameter } \\
\text { of bulb } \\
\text { (cm) }\end{array}$ & $\begin{array}{l}\text { Average } \\
\text { weight of } \\
\text { bulb (g) }\end{array}$ & $\begin{array}{c}\text { Total } \\
\text { yield of } \\
\text { bulb } \\
\left(\mathbf{q} \mathbf{h a}^{-1}\right)\end{array}$ & $\begin{array}{c}\text { Neck } \\
\text { thickness of } \\
\text { bulb }(\mathrm{cm})\end{array}$ & $\begin{array}{l}\text { T.S.S. of } \\
\text { bulb } \\
\left({ }^{0} \text { Brix }\right)\end{array}$ & $\begin{array}{l}\text { Water use } \\
\text { efficiency in } \\
\text { onion } \\
(q / h a-c m)\end{array}$ & $\begin{array}{l}\text { Gross } \\
\text { income } \\
\left(\boldsymbol{F} \mathbf{h a}^{-1}\right)\end{array}$ & $\begin{array}{l}\text { Net income } \\
\left(\mathcal{F} \mathbf{h a}^{-1}\right)\end{array}$ & $\begin{array}{l}\text { B:C } \\
\text { ratio }\end{array}$ \\
\hline \multicolumn{12}{|l|}{ Irrigation levels (I) } \\
\hline $\mathrm{I}_{1}(\mathrm{IW} / \mathrm{CPE}=1.0)$ & 4.49 & 4.53 & 4.89 & 76.48 & 260.94 & 1.58 & 12.14 & 6.129 & 260947 & 212234 & 4.36 \\
\hline $\mathrm{I}_{2}(\mathrm{IW} / \mathrm{CPE}=0.75)$ & 3.80 & 3.61 & 4.14 & 73.08 & 233.42 & 1.37 & 11.28 & 5.574 & 233423 & 185710 & 3.89 \\
\hline $\mathrm{I}_{3}(\mathrm{IW} / \mathrm{CPE}=0.50)$ & 3.64 & 2.77 & 3.60 & 63.77 & 206.82 & 0.92 & 10.95 & 4.985 & 206828 & 159115 & 3.33 \\
\hline S.Em \pm & 0.14 & 0.14 & 0.13 & 1.95 & 8.43 & 0.04 & 0.09 & 0.27 & 8431.00 & 8431.00 & 0.18 \\
\hline CD at $5 \%$ & 0.56 & 0.55 & 0.53 & 7.68 & 33.1 & 0.18 & 0.36 & 1.07 & 33104.21 & 33104.21 & 0.69 \\
\hline \multicolumn{12}{|l|}{ Varieties (V) } \\
\hline V $_{1}$ (NHRDF Red-1) & 3.66 & 3.32 & 3.81 & 56.86 & 206.60 & 1.17 & 10.10 & 4.929 & 206602 & 158556 & 3.30 \\
\hline V $_{2}$ (NHRDF Red-3) & 4.25 & 3.97 & 4.58 & 83.23 & 258.49 & 1.35 & 11.83 & 6.151 & 258496 & 210450 & 4.37 \\
\hline $\mathrm{V}_{3}$ (Agrifound Light Red) & 4.02 & 3.63 & 4.24 & 73.24 & 236.10 & 1.35 & 12.43 & 5.608 & 236099 & 188053 & 3.91 \\
\hline S.Em \pm & 0.11 & 0.15 & 0.12 & 1.98 & 7.53 & 0.04 & 0.30 & 0.16 & 7536.84 & 7536.84 & 0.16 \\
\hline CD at $5 \%$ & 0.33 & 0.46 & 0.38 & 6.10 & 23.22 & 0.14 & 0.94 & 0.48 & 23223.30 & 23223.30 & 0.49 \\
\hline
\end{tabular}


Neeraja et al., (1999) and Spehia et al., (2013) in onion have also found similar effect of irrigation on polar diameter of bulb. Varieties also had significant effect on polar diameter of bulb. In the present study variety $\mathrm{V}_{2}$ (NHRDF Red-3) recorded a higher mean value of polar diameter than the variety $V_{3}$ (Agrifound Light Red), while the minimum polar diameter was measured in case of variety $\mathrm{V}_{1}$ (NHRDF-Red-1). There was significant effect of irrigation levels on average weight of bulb. Among the irrigation levels the maximum average weight of bulb was recorded with irrigation level $I_{1}$ $(\mathrm{IW} / \mathrm{CPE}=1.00)$ which was followed by $\mathrm{I}_{2}$ $(\mathrm{IW} / \mathrm{CPE}=0.75)$ while the minimum average weight of bulb was recorded in case of irrigation level $\mathrm{I}_{3}$ (IW/CPE=0.50). These findings are similar in Rana and Sharma (1994), Neeraja et al., (1999) and Sharda et al., (2006). Varieties also had significant effect average weight of bulb. In the present experiment variety $\mathrm{V}_{2}$ (NHRDF Red-3) recorded higher average weight of bulb than the variety $\mathrm{V}_{3}$ (Agrifound Light Red), while the minimum weight of bulb was found with variety $\mathrm{V}_{1}$ (NHRDF-Red-1).

There was significant effect of irrigation levels on total yield of bulb (per hectare). Among the irrigation levels the maximum total yield of bulb was recorded with irrigation level $\mathrm{I}_{1}(\mathrm{IW} / \mathrm{CPE}=1.00)$ which was followed by $\mathrm{I}_{2}(\mathrm{IW} / \mathrm{CPE}=0.75)$ while the minimum total yield of bulb was recorded in case of irrigation level $\mathrm{I}_{3}$ (IW/CPE=0.50). These findings are similar with Neeraja et al., (1999), Sharda et al., (2006) and Spehia et al., (2013). Varieties also had significant effect on total yield of bulb. Data recorded in the present study indicated that variety $\mathrm{V}_{2}$ (NHRDF Red-3) recorded a higher mean value of total yield of bulb than the variety $V_{3}$ (Agrifound Light Red) while the minimum values was recorded variety $V_{1}$ (NHRDFRed-1).

\section{Quality parameters}

Quality parameters viz., neck thickness and total soluble solids were recorded under the study (Table 2). Irrigation level had exerted significant effect on neck thickness of bulb. Among the irrigation levels the maximum neck thickness of bulb was recorded with irrigation level $\mathrm{I}_{1}(\mathrm{IW} / \mathrm{CPE}=1.00)$ which was followed by $\mathrm{I}_{2}(\mathrm{IW} / \mathrm{CPE}=0.75)$. While the minimum neck thickness of bulb was recorded in case of irrigation level $\mathrm{I}_{3}$ (IW/CPE $=0.50$ ). These findings are similar in Metwally (2011). The data indicated significant effect of varieties on neck thickness of bulb at harvesting stage. In the present investigation cultivar $\mathrm{V}_{3}$ (Agrifound Light Red) and $\mathrm{V}_{2}$ (NHRDF Red-3) recorded maximum neck thickness. Minimum neck thickness was measured in case of cultivar $\mathrm{V}_{1}$ (NHRDF-Red-1). Significant differences among varieties for neck thickness have been also reported by Mohanty and Prusti (2001) and Devi et al., (2014) in onion.

The data indicated significant influence of irrigation levels on total soluble solids of bulb ( $\left.{ }^{\mathrm{B}} \mathrm{Brix}\right)$. Among the irrigation levels the maximum T.S.S. of bulb was recorded with irrigation level $\mathrm{I}_{1}(\mathrm{IW} / \mathrm{CPE}=1.00)$ which was followed by $\mathrm{I}_{2}(\mathrm{IW} / \mathrm{CPE}=0.75)$ while the minimum T.S.S. of bulb was recorded in case of irrigation level $\mathrm{I}_{3}$ (IW/CPE=0.50). These findings corroborates with those of Spehia et al., (2013). There was significant effect of varieties on total soluble solids of bulb. Observations on T.S.S. content in bulb revealed that cultivar $V_{3}$ (Agrifound Light Red) had maximum T.S.S. followed by the cultivar $\mathrm{V}_{2}$ (NHRDF-Red-3) while the minimum was recorded with cultivar $\mathrm{V}_{1}$ (NHRDF Red-1). The difference between variety $V_{2}$ and $V_{3}$ was non-significant indicating no difference in these two varieties. Similar result has been also reported by Devi et al., (2014). 


\section{Water use efficiency}

There was significant effect of irrigation level on water use efficiency in onion. Among the irrigation levels, $\mathrm{I}_{1}(\mathrm{IW} / \mathrm{CPE}=1.00)$ recorded maximum water use efficiency which was followed by $\mathrm{I}_{2}(\mathrm{IW} / \mathrm{CPE}=0.75)$ and minimum water use efficiency in $\mathrm{I}_{3}(\mathrm{IW} / \mathrm{CPE}=0.50)$. The highest water use efficiency is the optimum condition of irrigation level at which the crop yield per unit area is the highest with the optimum level of applied water. In the present study, favourable effect of irrigation at short intervals (Higher IW/CPE ratio) encouraged growth and yield attributes and yield and consequently resulted in higher water use efficiency. These findings corroborates with those of Bandyopadhyay and Malick (2003) and Spehia et al., (2013). There was significant effect of cultivars on water use efficiency in onion. Variety $\mathrm{V}_{2}$ (NHRDF Red3) recorded highest water use efficiency which was followed by variety $V_{3}$ (Agrifound Light Red). The minimum water use efficiency was recorded in case of variety $\mathrm{V}_{1}$ (NHRDF Red-1).

\section{Economic of treatments}

Observations showed that Irrigation levels and varieties had significant effect on gross income, net income and B: C ratio. Highest gross income, net income and $\mathrm{B}$ : $\mathrm{C}$ ratio was found with irrigation level $\mathrm{I}_{1}(\mathrm{IW} / \mathrm{CPE}=1.00)$ followed by $\mathrm{I}_{2}$ and least was found in $\mathrm{I}_{3}$ among the varieties maximum gross income, net income and $\mathrm{B}$ : $\mathrm{C}$ ratio was recorded with variety $\mathrm{V}_{2}$ (NHRDF-Red-3). Similar results were also reported by Silabut et al., (2014) in garlic.

It can be concluded from the study that irrigation regime $\mathrm{I}_{1}(\mathrm{IW} / \mathrm{CPE}=1.00)$ seems to be optimum for water saving, bulb yield and economic productivity point of view. The variety $\mathrm{V}_{2}$ (NHRDF- Red-3) performed better for growth attributes, yield and yield attributes, water use efficiency and economic productivity.

\section{References}

Abd El-Kader, A.A., Shaaban, S.M., and Abd El-Fattah, M.S. 2010. Effect of irrigation levels and organic compost on okra plants (Abelmoschus esculentus L.) grown in sandy calcareous soil. Agric. Biol. J. N. Am.1 (3):225-231.

Abd El-Samad, E.H., Khalifa, R.Kh. M., Lashine, Z.A., Shafeek, M.R. 2011. Influence of Urea fertilization and foliar application of some micronutrients on growth, yield and bulb quality of onion. Aust. J. Basic Appl. Sci., 5(5): 96-103.

Bandyopadhyay, P.K. and Malick, S. 2003. Actual evaporation and crop coefficient of onion under varying soil moisture levels in the humid tropics of India. Trop. Agric., 80 (2):1-8.

Biswas, S.K., Khair, A. and Sarker, P. K. 2010. Yield of onion and leaf purple blotch incidence as influenced by different levels of irrigation. Agric. Tropic et Subtropic. 42(2): 85-91.

Devi, A.P., Kale, V.S., Patil, R. and Moirangthem, S.S. 2014. Perfprmence of different rabi onion varieties under Akola conditions. Int. Res. J. of Natural and Applied Sci. 1(6): 2349-4077.

Jogdande, N.D., Gajbhiye, R.P. and Ganvir, G.B. 2011. Performance of onion genotypes for growth and yield parameters under Akola conditions. Green Farming, 2 (5): 548-549.

Metwally, A.K. 2011. Effect of water supply on vegetative growth and yield characteristics in onion (Allium cepa L.). Aust. J. Basic Appl. Sci., 5(12): 3016-3023.

Mohanty, B. K. and Prusti, A. M. 2001. Performance of common onion (Allium 
сера) varieties in kharif seasons. $J$. Trop. Agric. 39: 21-23.

Neeraja, G., Reddy, K.M., Reddy, I.P. and Reddy, Y.N. 1999. Effect of irrigation and nitrogen on growth, yield and yield attributes of rabi onion (Allium cepa $\mathrm{L}$.) in Andhra Pradesh. Veg. Sci. 26(1): 6468.

Rana, D.S. and Sharma, R.P. 1994. Effect of irrigation regime and nitrogen fertilization of bulb yield and water use of onion. Indian J. Agric. Sci. 64 (4):223-226.

Sammis, T.W., Al-Jammal, M.S., ball, S. and Smeal, D. 2000. Crop water use of onion. In: Proceedings of sixth International Micro irrigation Congress, Micro 2000,Cape Town, South Africa, 22-27 October 2000, pp.1-9.

Sharda, R., Mahajan, G., Kaushal, M.P., Chawla, N. and Bal, S.S. 2006. Effect of irrigation on yield and quality of onion. Veg. Sci. 33(1): 34-37.

Silabut, N., Naruka, I. S., Shaktawat, K. S., Verma, K. S. and Seyie, A. 2014. Response of garlic cultivars to irrigation levels. Indian J Hort. 71(3): 354-359.

Singh, R. and Alderfer, R. 1966. Effect of soil moisture stress at different period of growth of some vegetable crops. Soil Sci. 101(1): 69-80.

Spehiya, R.S., Sharma, V., Raina, J. N., Pathania, S. and Bhardwaj, R.K. 2013. Effect of irrigation levels and polyethylene mulching on growth, yield and quality of rabi onion (Allium cepa L.). Indian J. Agric. Sci. 83(11): 1184-8. Yumnam, A., Mandal, A. R., Thapa, U., Maity, T. K. and Bhattacharya, S. P. 2009. Studies on weed management in onion (Allium cepa L.). J Crop Weed., 5(1): 325-326.

\section{How to cite this article:}

Nisha Nandle, R.K. Sharma, S.S. Kushwah and Roshan Gallani. 2018. Effect of Irrigation Regimes and Varieties on Growth, Bulb Yield and Quality of Onion (Allium cepa L.). Int.J.Curr.Microbiol.App.Sci. 7(05): 1104-1111. doi: https://doi.org/10.20546/ijcmas.2018.705.135 